\title{
Situation-based Learning Model Implementation through Thematic Learning as an Effort to Improve the Primary School Students' CPS Ability
}

\author{
Muhamad Ramdan ${ }^{\circledR}$, Nurdinah Hanifah², I. Isrokatun ${ }^{3}$ \\ 1 MI Cikapayang, Bandung, Indonesia \\ 2,3 Elementary Teacher Education Program, Universitas Pendidikan Indonesia, Sumedang, Indonesia \\ $\triangle$ muhamadramdan213@student.upi.edu
}

\begin{abstract}
This research aims at measuring the improvement of the students' CPS ability through the SBL model implementation through thematic learning. This research employed a quasiexperimental design with non-equivalent control group design involving all fourth grade students in public primary schools in Sumedang Regency. Meanwhile, the sample used in the research was one of public primary schools in North of Sumedang Regency by determining that 30 students of class IV-A included in the experimental class, and 32 students of class IV-B included in the control class. Based on the test instrument of CPS ability, the research results revealed that the SBL model implementation was able to improve significantly the CPS ability in thematic learning in the experimental class.
\end{abstract}

Keywords: CPS Ability, SBL Model, Thematic Learning

How to Cite: Ramdan, M., Hanifah, N., Isrokatun, I. (2019). Situation-based Learning Model Implementation through Thematic Learning as an Effort Improve the Primary School Students' CPS ability. Mimbar Sekolah Dasar, 6(3), 304-316. DOI: 10.17509/mimbar-sd.v6i3.19075

INTRODUCTION The significant role of education in a country makes education as a necessity for all people. Permendikbud No. 20 of 2016 confirms that national education serves to develop capabilities, and forms the dignified character and civilization of the nation in order to develop the nation's intellectual life. In addition, according to Permendikbud No. 22 In 2016, students are required to be faithful to God Almighty, have good character (honest, caring, responsibility), and have healthy body and soul. Students must also have factual, conceptual, procedural, and metacognitive knowledge related to science and technology, arts and culture. Students also must have thinking and active skills (creative, productive, critical, independent, collaborative, and communicative), so that the learning process must be interactive, inspiring, fun, and challenging; motivate students to participate actively; provide adequate space, creativity, and independence in accordance with the talents, interests and physical and psychological development of students.

Some of the learning problems, such as learning that emphasizes asking questions rather than presenting questions, lead to lack of student awareness of the problem. 
Muhamad Ramdan, Nurdinah Hanifah \& Isrok'atun, Situation-based Learning Model Implementation...

This results in weak ability of problem finding, so that the students' ability of idea finding and problem-solving also become weak (Isrok'atun, 2014; Isrok'atun \& Tiurna, 2014).

However, as implied in the Law No. 20 of 2003 on the National Education System, Article 3, it is explained that the purpose of national education is to develop the students' potentials to become persons who are faithful and pious to God Almighty; have good morality, healthy body and soul, knowledgeable, capable, creative, independent; and a democratic and responsible citizen. Therefore, the learning must be designed to realize what is the goal of national education.

Another aspects that needs to be taken into consideration is the role of social studies subjects designed to develop knowledge related to life in society. This ability is expected to be possessed by students to enter a dynamic community life. The purposes of social studies learning at the primary school level in Permendiknas No. 22 of 2006 are as follows.

1. Recognizing the concepts relating to people's lives and their environment.

2. Having the basic ability to think logically and critically, curiosity, inquiry, problemsolving, and skills in social life.

3. Having commitment and awareness of social and human values.

4. Having the ability to communicate, collaborate and compete in a pluralistic society in the local, national and global level.

Therefore, a planned activity is clearly required to make students active in the learning process, only through the involvement or activeness of students in the learning process, that is able to develop their potential and creativity. In fact, there are efforts to develop creativity at this time has not been done much. The ability to think creatively does not develop by itself, but it requires preparation, one of which is through the educational process.

A model that can explore students' abilities in understanding, presenting, and solving problems is the SBL model. Tarek et al. (in Isrok'atun \& Tiurlina, 2016) explained that SLB is a new strong and flexible approach in constructing constructivist learning paradigms.

In addition, there are several related studies that have been conducted, including a research conducted by Isrok'atun \& Tiurlina (2014) entitled "Proses Belajar Matematika Menggunakan LKS Berbasis Situation-Based Learning pada Materi Bangun Ruang di SDN 9 Kota Serang (Mathematics Learning Process Using SBL's Students Worksheet on Geometric Material in SDN 9 Kota Serang", Isrok'atun \& Tiurlina (2015) entitled "Upaya Meningkatkan Kemampuan CPS Siswa melalui Pembelajaran SBL di Sekolah Dasar ("Efforts to Improve the Students' CPS Ability through SBL Learning in Primary Schools", Sowanto (2015) entitled "Situation-Based Learning 
Berbantuan Program Geometer's Sketchpad (GPS) untuk Meningkatkan Kemampuan Representasi Matematis dan Self-Efficacy Siswa SMP ("SBL-assisted GPS Program to Improve Mathematical and Self-Representative Capabilities Efficacy of Junior High School Students)", Larawati (2016) entitled "Penerapan Model Situation-Based Learning (Application of Situation-Based Learning Model)", and Sari et al. (2016) entitled "Pembelajaran Situation-Based Learning dengan Metode Two-Stay Two Stray untuk Meningkatkan Kemampuan Komunikasi Matematis pada Siswa Sekolah Dasar (SBL with the Two-Stay Two Stray Method to Improve Mathematical Communication Skills in Primary School Students)", Aqilah (2017) entitled "Situation-Based Learning dalam Upaya Meningkatkan Kemampuan Creative Problem Solving Matematis Siswa (Situation-Based Learning in an Effort to Improve Students' Mathematical Creative Problem Solving Ability)", dan Suhaebar (2018) entitled "'Pengaruh Situation-Based Learning Terhadap Kemampuan Creative Problem Solving dan Kemandirian Belajar Siswa (Penelitian Eksperimen Kuasi pada Materi Persegi panjang dan Peristiwa Alam Secara Integratif Siswa Kelas $V$ SD di Kecamatan Tanjungsari, Kabupaten Sumedang) ("The Effect of Situation-Based Learning on Students' Creative Problem Solving Ability and Learning Independence (A Quasi-Experimental Research on Rectangular and Natural Events Materials Integrally in Fifth Grade Primary School Students in Tanjungsari Sub-
District, Sumedang Regency)" as well as a research conducted by Widodo \& Kartikasari (2017) one of primary schools in in Munjuljaya sub-district, which the results of the fourth-grade students' CPS ability pre-tests revealed that the average score of the experimental class was 13.2, and the average score of the control class was 12.6 .

All of the research were focused on science and mathematics subjects, while this research is directed at thematic learning with a focus on social studies subjects on how the application of the SBL model that can improve the CPS ability.

The CPS (Creative Problem Solving) ability in the problem solving process requires creative abilities. Creative abilities are needed in finding ideas or thoughts that are possible to resolve the situation at hand. Some research results on CPS ellaborate that CPS starts with divergent thinking, and ends with convergent thinking. Divergent thinking is the way of thinking spreadly, or the process of exploring various possible ideas, while convergent thinking is the way of thinking collectively, or the process of choosing or taking the best ideas from a variety of possible ideas (Isrok'atun, 2012; Isrok'atun \& Tiurlina, 2015).

The CPS ability is the ability to solve problems in creative and unique ways. The CPS ability provides flexibility to students to explore in an effort to solve problems in their own way. In the process of solving the problem, creative abilities are required to 
Muhamad Ramdan, Nurdinah Hanifah \& Isrok'atun, Situation-based Learning Model Implementation...

find ideas or thoughts that are possible to resolve the situation at hand.

\section{The Creative Problem Solving (CPS) Ability}

According to Mitchell \& Kowalik (1999), CPS is a method, process, or system of approaching a problem with an imaginative process in which it solves problems creatively, and produces effective actions. While, according to Isrok'atun (2012), CPS is the ability to find a variety of ideas or thoughts to seek various possible effective actions in the problemsolving process. In other words, CPS is an ability that specializes in solving complex and open-ended problems, so that, even in the process of solving problems, the answers or solutions may vary. The aspects of CPS ability stated by Parnes (in Isrok'atun, 2018) are as follows. 1) Objective finding is an effort to identify information contained in a situation, and challenges and objectives to be resolved.

2) Fact finding is an effort to find important information that is less visible, and explore data that is still related to the situation. 3 ) Problem finding is an effort to observe and analyze the statement of the problem, then choose which statement of the problem needs to be solved. 4) Idea finding is an effort to express various ideas, and identify possible solutions to solve the problems that have been chosen previously. 5) Solution finding is an effort to choose the best solution from the list of proposed solutions in the previous aspect to solve the problem. 6) Acceptance finding is an effort to improve the carrying capacity of the solutions that have been chosen either with different steps, methods, or answers.

\section{The Situation-Based Learning (SBL) Model}

According to Tarek et al. (in Isrok'atun \& Tiurlina, 2016), SBL a strong and flexible approach in developing constructive learning. Students will learn a lot when faced with a situation, then it will trigger students to seek and think the solutions, and construct their own knowledge. The $\mathrm{SBL}$ is aimed at training and also developing the students' problem-posing, problem-understanding, and problemsolving abilities. Problem-posing is the students' ability to ask questions from situations that have been presented by the teacher. The questions are related to the concepts of social science, mathematics and science, which can be solved. In addition, problem-understanding is the students' ability to understand the problems with their understanding that can trigger them to carry out the thought process and also develop solutions as an effort to solve the problem. Furthermore, problem solving is a follow-up to understanding the problem in which at this stage, students look for various solutions to solve the problem. According to Isrokatun et al. (2019), this SBL consists of four stages of the learning process, namely: 1) creating the situation; 2) problem-posing; 3) problem-solving; and 4) applying the concept.

Creating the situation is the requirements in implementing SBL. In this first stage, the 
teacher creates a situation that leads students to the process of observation and exploration independently, then, the student can create questions from that situation.

Problem posing is considered as a core stage of SBL. In this second stage, the students are required to create questions from the situation presented by the teacher, the questions are related to characteristic of social studies, mathematics and science ranging from low to high levels, questions that cannot be answered, questions to be answered easily, to questions of complex problems that require the CPS ability. According to Probst \& Gomez (in Steiner, 2009, 8), based on the level of difficulty, the problems are categorized into simple, complicated, and complex problems. Simple problem tends to be able to be solved easily, and also contain a few elements with relatively few links. Complicated problem is similar to simple problems, but in it has a comparison of each element that is interrelated with one another. Moreover, in simple problem, the problem can be solved only by using standard methods or methods, but in complicated problem, the problem must be solved with more complex methods, it is because complicated problems have many elements that requires several stages. Although there is a difference between simple problem and complicated problem, both of them can be solved by means or methods resulting from the process of thinking of routine problem-solving. Meanwhile, the complex problem presents a more difficult levels of problems, which in the solution process, it cannot be solved based on a routine problem-solving process. Complex problem has unknown and ambiguous problem-solving characteristics, thus basic knowledge/ability that can support and creative ways to solve their problems are needed. Therefore, complex problem must be solved with the creative problemsolving process (Isrok'atun, 2012).

The next stage or the third stage is problem-solving, which is considered as the goal of SBL. At this stage, students solve problems from the students' questions asked in the previous stage.

The last stage is applying the concept, which is the application of the learning process to a new situation. At this last stage, students are expected to apply the results of the SBL process in the form of knowledge or understanding in new social, mathematical and natural science situations related to daily life. In the process, the SBL model can develop the CPS ability in mathematics (Isrok'atun, 2016), In addition, this model is really able to make students have characters who are able to face a variety of different or new situations. In other words, learning motivation has occurred for students (Isrok'atun \& Tiurlina, 2016). The stages of the SBL model according to Isrok'atun, Maulana \& Irawati (2017), and Isrok'atun, Hanifah \& Maulana (2018) are presented in Figure 1. 


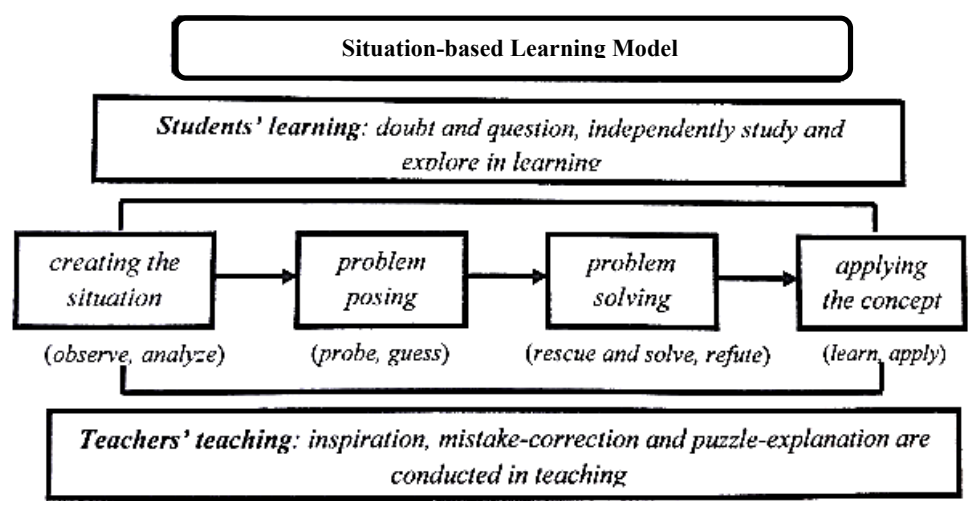

Figure 1. The Stages of Situation-Based Learning (SBL) Model

\section{Thematic Learning}

According to Hidayat (in Anggraini, 2014), thematic learning is an integrated learning that uses themes as a unifying material contained in several subjects, and given in one face-to-face. According to Rusman (2015), thematic learning is a learning system that allows students to actively explore and discover meaningful scientific concepts and principles. According to Hanifah (2014), thematic learning combines various subjects by using certain themes. The themes cover various perspective, so that it gives meaning to students. Trianto (in Utari, 2016) states that thematic learning is interpreted as learning that is designed based on certain themes. The intended theme is a theme that emerges from the identification or various existing subjects. Based on the aforementioned explanations, thematic learning can be defined as meaningful learning that combines several themebased subjects. There are several characteristics that need to be understood from thematic learning (Hernawan in
Yuniasih, 2014), namely: 1) Studentcentered, the teacher's role is more as a facilitator who facilitates students in carrying out learning activities. 2) Direct experience to students, students are faced with tangible (concrete) situation as a basis for understanding more abstract concepts. 3) Categorizations between subjects becomes less clear, so that the focus of learning is directed at discussing themes that are most closely related to students' real lives. 4) Presentation of concepts from various subjects in the learning process, students can understand these concepts in their entirety. 5) Flexibility, teachers can connect teaching materials from one subject with other subjects. 6) Learning outcomes can develop in accordance with the interests and needs of students, students are given the opportunity to optimize their potential.

\section{METHODS}

\section{Research Method}

This research employed a quasiexperimental research method. A Quasiexperiment is a research to find the causal 
relationship of one variable towards another without any random selection of research subjects (Maulana, 2009; Sudjana \& Ibrahim, 2014).

\section{Research Design}

A quasi-experimental was used with involving the students who had been determined. According to Arifin (2012), a quasi-experimental method basically aims at predicting the conditions that can be achieved by pure experimental research actually, but without the control and/or manipulation of all relevant variables.

This research used a quasi-experimental study proposed by Maulana (2009) with a non-equivalent control group design. The design of the non-equivalent control group design is as follows.

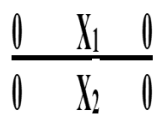

Information:

0 : Pre-test and Post-test

$\mathrm{X} 1$ : Treatment using the SBL model

$\mathrm{X} 2$ : Treatment using the conventional model

\section{Research Site}

This research was conducted at one of primary schools located at North Sumedang Sub-District, Sumedang Regency.

\section{Research Subject}

The research involved all fifth-grade students in primary schools in North
Sumedang Sub-district, Sumedang Regency. The sampling technique used in this research was non-probability sampling with more specialized purposive sampling, which is used to achieve certain goals and based on certain considerations. McMillan \& Schumacher (in Maulana, 2009) said that in an experimental research, the minimum number of samples was 30 subjects per group. The research selected a public elementary school in North Sumedang District as the sample research. This was based on several reasons, such as the number of students who were eligible to conduct experimental research, namely at least 30 subjects per group, then the location of the primary school that is strategic, and reachable by a variety of transportation. In addition, other considerations in choosing this public primary school was because in the fourth grade, there are two study groups (rombel - rombongan belajar), in which the number of students in each class was more than 30. Thus, it had fulfilled one of the requirements of experimental research. The research used a non-equivalent control group design, Therefore, the selection of the experimental class and the control class was not done randomly. Thus, class IV-A was chosen as the experimental class, while class-IV B was the control class.

\section{Data Collection Technique}

The quantitative data were collected in this research. The data were obtained from pre-test and post-test data on the CPS ability test, this instrument test was 
Muhamad Ramdan, Nurdinah Hanifah \& Isrok'atun, Situation-based Learning Model Implementation...

used as a measure of students' CPS ability to obtain sufficiently complete data instruments as in previous studies. This CPS ability test was in the form of essay questions based on the theme 1, subtheme 1, class IV about the types of work, square area, and caring and preserving natural resources that have been in accordance with the CPS indicators. This test is carried out twice, namely the initial test (pre-test) and the final test (post-test). Pre-test is conducted to measure the students' CPS ability before conducting learning, both in the experimental class and the control class. While the post-test, is used to measure the extent of the development of CPS ability after conducting learning, both in the experimental class and the control class. The characteristics of the questions in the pre-test and post-test are similar, both in the experimental class and the control class. The test is started by preparing questions outline, the questions are created in the form of essays. Then, scoring guidelines for each item are processed. The students' CPS ability questions that have previously been validated by experts, then are tested on other students outside the population.

\section{Data Processing and Analysis Technique}

Data collection on the results of the CPS ability test was carried out conducting the pre-test and post-test. Data collected from the results of the pre-test and post-test then were averaged, both from the experimental class or the control class. After obtaining the average of the pre-test and post-test, then the analysis was conducted through the normality test, homogeneity test, paired difference test and normalized gain test. The statistical test was also assisted by the IBM Statistics 22 software.

\section{RESULT}

\section{Improving Student CPS Ability Through the} SBL Implementation

Based on the aforementioned problem formulation, the section elaborated the gain scores resulting from the treatment given, the treatment was in the form of the SBL implementation in the experimental class, and the implementation of conventional learning in the control class. The analysis of the pre-test and post-test scores in the experimental class was conducted to find out the improvement in students' CPS ability through the SBL implementation. Based on the recapitulation of the pre-test and post-test scores on all students' CPS ability in the experimental class, the average pre-test score was 37.17, while the average posttest score was 74.33. The summary of the average score of pre-test and post-test in the experimental class, is presented in Table 4.1. 
Table 4.1 Summary of Pre-test and Post-test Score of the CPS Ability in the Experimental Class

\begin{tabular}{cccccc}
\hline Score & Score Range & $\begin{array}{c}\text { Lowest } \\
\text { Score }\end{array}$ & $\begin{array}{c}\text { Highest } \\
\text { Score }\end{array}$ & $\begin{array}{c}\text { Average } \\
\text { Score }\end{array}$ & $\begin{array}{c}\text { Standard } \\
\text { Deviation }\end{array}$ \\
\hline Pre-test & $0-100$ & 0.50 & 80.00 & 37.17 & 17.69 \\
\hline Post-test & $0-100$ & 20.00 & 100.00 & 74.33 & 15.29 \\
\hline
\end{tabular}

Table 4.1 shows that there was an increase in the students' CPS ability from the SBL implementation in the experimental class. However, to find out whether or not the increase was significant, it was necessary to conduct pair difference test. Before conducting the pair difference test, the results of the pre-test and post-test scores in the experimental class were tested for normality in order to know whether the data were normally or not normally distributed. Moreover, the data were not needed to be tested in homogeneity test, because the sample tested was indicated as a dependent sample, thus the variance was assumed to be similar. After conducting statistical tests, namely the normality test and the paired difference test, the results of statistical tests on the pre-test and post-test scores of the CPS ability in the experimental class was obtained as follows.

Table 4.2 Summary of Statistical Tests on Pre-test and Post-test Results of the CPS Ability in Experimental Class

\begin{tabular}{ccccc}
\hline Score & Average & $\begin{array}{c}\text { Standard } \\
\text { Deviation }\end{array}$ & $\begin{array}{c}\text { Normality Test } \\
\text { (Shapiro-Wilk) }\end{array}$ & $\begin{array}{c}\text { Paired Difference Test } \\
\text { W-Test(Wilcoxon) }\end{array}$ \\
\hline Pre-test & 37.17 & 17.69 & $\begin{array}{c}\text { Normally } \\
\text { Distributed }\end{array}$ & There is a difference \\
\cline { 1 - 3 } Post-test & 74.30 & 15.29 & $\begin{array}{c}\text { Not Normally } \\
\text { Distributed }\end{array}$ & \\
\hline
\end{tabular}

Table 4.2 shows that there were significant differences in the average between the pre-test and post-test results in the experimental class. To find out the improvement in the CPS ability through the
SBL implementation, an analysis of gain scores of the students' CPS ability was carried out. The gain of the students' CPS ability in the experimental class is presented in Table 4.3. 
Muhamad Ramdan, Nurdinah Hanifah \& Isrok'atun, Situation-based Learning Model Implementation...

Table 4.3 Gain of the Students' CPS Ability in the Experimental Class

\begin{tabular}{ccccccc}
\hline \multicolumn{2}{c}{ Pre-test } & \multicolumn{2}{c}{ Post-test } & \multicolumn{2}{c}{ Gain } & Gain \\
\cline { 1 - 5 } Average & $\begin{array}{c}\text { Standard } \\
\text { Deviation }\end{array}$ & Average & $\begin{array}{c}\text { Standard } \\
\text { Deviation }\end{array}$ & Average & $\begin{array}{c}\text { Standard } \\
\text { Deviation }\end{array}$ & Category \\
\cline { 3 - 6 } 37.17 & 17.69 & 74.30 & 15.29 & 0.60 & 0.20 & Moderate \\
\hline
\end{tabular}

Table 4.3 shows that there was an increase (gain) in CPS students' ability by 0.60 . The score was obtained based on the average gain of each student in the experimental class. Therefore, it was concluded that the $\mathrm{SBL}$ implementation could improve the students' CPS ability. Based on the analysis that had been conducted, the result revealed that the hypothesis was accepted, or the "SBL can improve the students' CPS ability" was true.

\section{DISCUSSION}

\section{The SBL Implementation towards the Improvements of the CPS Ability}

In this research, the $\mathrm{SBL}$ implementation provided an increase in the students' CPS ability. This was indicated by the increasing of the average score of the students' CPS ability in the experimental class in which the average score of CPS pre-test ability in the experimental class was 37.17 , while the average score of post-test was 74.33. Thus, an average gain of 0.60 was obtained. After conducting the paired difference test, the results showed that there was an average difference between the pre-test and post-test results of the students' CPS ability in the experimental class. Therefore, it revealed that the SBL significantly improve the students' CPS ability in the experimental class. In other words, the SBL process is able to develop the students' CPS ability (Isrok'atun \& Tiurlina, 2016; Aqilah, 2017). An increase of the students' CPS ability who been treated using the SBL was affected by the situation faced by students in accomplishing their worksheets, that led students to observe and investigate situations, make questions, find solutions to solve, and also apply solutions. Through these activities, the students were able to develop the ability of problemposing, problem-understanding, and problem-solving, which became the purpose of SBL (Isrok'atun \& Tiurlina, 2014; Isrok'atun, Hanifah \& Maulana, 2019).

SBL had been proven to significantly improve the students' CPS ability. The CP ability can also support the achievement of learning, especially in social studies, mathematics and science subjects. In the standard contents of primary school subjects, one of the main objectives of social studies learning in primary schools is to make students have problem-solving abilities. Furthermore, according to the Ministry of National Education (in Effendi, 2012), the purpose of mathematics subjects for all levels of primary and secondary education is to make students be able to solve problems. This results are 
proven by several studies that have been carried out, for instances, Fatoni (2014) whp stated that cooperative learning of creative problem-solving (CPS) assisted by hot seats had an effect on social studies learning outcomes, then according to Ruskandi (2016) the implementation of creative problem-solving in social studies learning processes was able to improve the students' problem-solving ability and learning outcomes. Puspitasari (2018) revealed that the implementation of CPS on the concept of style was able to improve student learning outcomes, and Yulianti \& Lestari (2019) revealed that the implementation of CPS learning model was able to improve the primary school students' learning outcomes of science learning. Therefore, it is necessary to implement the SBL in all three subjects in order to improve the students' CPS ability, and achieve the desired goals, namely so that the students can have a good ability to solve problems.

\section{CONCLUSION}

SBL is able to improve the students' CPS ability. This improvement is shown by the increase in the students' CPS ability in the class that implement the SBL in the medium category. Learning with SBL assisted by the student worksheets has a significant role in the success of the SBL, because the worksheet contains every stage of SBL that can develop the students' CPS ability.

\section{REFERENCES}

Anggraini, C. C., \& Untari, M. F. (2014). Keefektifan Model Permainan BoyBoyan terhadap Hasil Belajar Tema "Diriku" Siswa Kelas I SD. Mimbar Sekolah Dasar, 1(1) 92-98. https://doi.org/10.17509/mimbarsd.v1i1.869

Aqilah, B. (2017). Situation-Based Learning dalam Upaya Meningkatkan Kemampuan Creative Problem Solving Matematis Siswa. (Undergraduate Thesis). PGSD, Universitas Pendidikan Indonesia, Sumedang, Indonesia.

Effendi, L. A. (2012). Pembelajaran Matematika dengan Metode Penemuan Terbimbing untuk Meningkatkan Kemampuan Representasi dan Pemecahan Masalah Matematis Siswa SMP. Jurnal Penelitian Pendidikan, 13(2), 1-10. Retrieved from http://jurnal.upi.edu/index.php/downl oad/pdf/1852/pembelajaranmatematika-dengan-metodepenemuan-terbimbing-untukmeningkatkan-kemampuanrepresentasi-dan-pemecahanmasalah-matematis-siswa-smp.pdf

Fatoni, A., Ganin, N. N., \& Manuaba, I. S. (2014). Pembelajaran Kooperatif Tipe Creative Problem Solving (CPS) Berbantuan Kursi Panas Berpengaruh Terhadap Hasil Belajar IPS Siswa Kelas $\checkmark$ SD Gugus Ir. Soekarno. Jurnal Mimbar PGSD Universitas Pendidikan Ganesha, 2(1), 1-10. http://dx.doi.org/10.23887/jjpgsd.v2i 1 . 3191

Hanifah, N. (2014). Resensi Buku: Membuka Pikiran Menuju Keterpaduan. Jurnal Mimbar Sekolah Dasar. 1(1), 108-112. https://doi.org/10.17509/mimbarsd.v1il.871

Isrok'atun. (2012). Creative problem solving (CPS) mathematics. Proceeding of Seminar Nasional Matematika dan Pendidikan Matematika FMIPA UNY. 437-449. Yogyakarta.

Isrok'atun \& Tiurlina. (2014). Situation-Based Learning untuk Meningkatkan 
Muhamad Ramdan, Nurdinah Hanifah \& Isrok'atun, Situation-based Learning Model Implementation...

Kemampuan Creative Problem Solving Matematis Siswa SD. Mimbar Sekolah Dasar, 1 (2),. 209-216. https://doi.org/10.17509/mimbarsd.vli2.885

Isrok'atun. (2016). Pendidikan Matematika II. Sumedang: UPI Sumedang Press.

Isrok'atun \& Tiurlina. (2016). Model pembelajaran matematika situationbased learning di sekolah dasar. Sumedang: UPI Sumedang Press.

Isrok'atun, Maulana, \& Irawati, R. (2017). Model situation-based learning (SBL) untuk meningkatkan kemampuan creative problem solving (SBL) matematis siswa sekolah dasar. Laporan Tahunan Penelitian Hibah Bersaing. Unpublished Manuscript.

Isrok'atun. (2018). Rendahnya kemampuan Acceptance Finding Siswa Sekolah Dasar. Proceeding of Seminar Nasional SNMPM Unswagati, 1-7.

Isrok'atun, I., Hanifah, N., \& Maulana, M. (2018). Acceptance finding ability. Presented in 3rd Annual Applied Science and Engineering Conference (AASEC 2018) IOP Conf. Ser.: Mater. SCi. Eng. $434 \quad 012295$

Isrok'atun, I., Hanifah, N., \& Maulana, M. (2019), Scaffolding dalam Situation Based Learning. Sumedang: UPI Sumedang Press

Isrokatun, I., Anggita, D., Purwono, B. S., Sunaengsih, C. \& Syahid, A A. (2019). Scaffolding in conceptual science. Presented in IOP Conf. Ser.: Mater. Sci. Eng. 1402044079

Maulana. (2009). Memahami hakikat, variabel, dan instrumen penelitian pendidikan dengan benar. Bandung: Learn2live 'n live2learn.

Mitchell, W. E., \& Kowalik, T. F. (1999). Creative problem solving. NUCEA: Genigraphict Inc.

Permendiknas No. 22 Tahun 2006. Kerangka Dasar dan Struktur Kurikulum. [Online]. Available on www.bphn.go.id/data/documents/06 pmdik022.pdf
Permendikbud No. 20 Tahun 2016. Standar Kompetensi Lulusan. [Online]. Available on http://bsnpindonesia.org/wpcontent/uploads/2009/04/Permend ikbud_Tahun2016_Nomor020.pdf

Permendikbud No. 22 Tahun 2016. Standar Proses. [Online]. Available on https://bsnp-indonesia.org/wp/uploads/2009/06/Permendikbud_Tah un2016_Nomor022_Lampiran.pdf

Puspitasari, N. W. (2018). Penerapan Pendekatan Creative Problem Solving (CPS) pada Konsep "Gaya" untuk Meningkatkan Hasil Belajar Siswa. Jurnal Pendidikan, 19(1). 53-67. https://doi.org/10.33830/jp.v19i1.150.2 018

Ruskandi, K. (2016). Penerapan Metode Problem Solving untuk Meningkatkan Kemampuan Pemecahan Masalah Siswa dalam Pembelajaran IPS di Sekolah Dasar. Jurnal Metodi Didaktik, 10(2), 66-73. https://doi.org/10.17509/md.v10i2.318 4

Rusman. (2015). Pembelajaran Tematik Terpadu. Depok: PT Rajagrafindo Persada.

Steiner, G. (2009). The Concept of Open Creativity: Collaborative Creative Problem Solving for Innovation Generation-A Systems Approach. Journal of Business and Management, 15(1), 5-33. Retrieved from http://jbm.johogo.com/pdf/volume/1 501/JBM-1501-01-full.pdf

Suhaebar, Is. (2018). Pengaruh SituationBased Learning terhadap Kemampuan Creative Problem Solving dan Kemandirian Belajar Siswa. (Undergraduate Thesis). PGSD, Universitas Pendidikan Indonesia, Sumedang, Indonesia.

Syafni, E., Syukur, Y., \& Ibrahim, I. (2013). Masalah Belajar Siswa dan Penangannya. Jurnal IImiah Konseling, 2(2), 15-19. https://doi.org/10.24036/020132217210-00 
Utari, U., Degeng, I. N., \& Akbar, S. (2016). Pembelajaran Tematik Berbasis Kearifan Lokal di Sekolah Dasar dalam Menghadapi Masyarakat Ekonomi Asean (MEA). Jurnal Teori dan Praksis Pembelajaran IPS, 1(1), 39-44. https://doi.org/10.17977/um022v1i1201 6p039

UU No. 20 Tahun 2003. Sistem Pendidikan Nasional. [Online]. Available on https://kelembagaan.ristekdikti.go.id/ wpcontent/uploads/.../UU_no_20_th_2003 .pdf

Yulianti, Y., \& Lestari, I. (2019). Penerapan Model Creative Problem Solving untuk
Meningkatkan Hasil Belajar Siswa pada Pembelajaran IImu Pengetahuan Alam Di Sekolah Dasar. Jurnal Cakrawala Pendas, 5(1), 32-39. Retrieved from https://www.neliti.com/id/publications /280138/penerapan-model-creativeproblem-solving-untuk-meningkatkanhasil-belajar-siswa\#cite

Yuniasih, N., Ladamay, I., \& Wahyuningtyas, D. T. (2014). Analisis Pembelajaran Tematik pada Kurikulum 2013 DI SDN Tanjungrejo 1 Malang. Mimbar Sekolah Dasar, 1(2), 148-152. https://doi.org/10.17509/mimbarsd.vli2.876. 